\title{
OBSERVATIONS ON CHYTRIDIACEOUS PARASITES OF PHANEROGAMS. III. PHYSODERMA CLAYTONIANA AND AN ASSOCIATED PARASITE ${ }^{1}$
}

\section{F. K. Sparrow}

IN 1944, H. C. Greene (1944) published a brief description of a new species of Physoderma parasitic on the leaves of one of our most exquisite spring wild flowers, Claytonia virginica. The report was of interest, not only because, as Greene pointed out, there have been no previous reports of Physoder$m a$ on members of the Portulacaceae, but also for the reason that this parasite of so common a wildflower had so long remained unknown. The latter fact may possibly be attributed to the superficial resemblance of the Physoderma and the telial stage of the common Spring Beauty rust, Puccinia Mariae-Wilsoni.

During 1944 and 1945 material of Spring Beauty infected with a leaf and stem spotting fungus was brought by Mr. Hazen Price from his farm at Amherstburg, Ontario, to the mycology laboratories for examination. Some of this was turned over to the writer by Prof. L. E. Wehmeyer for confirmation of his identification of the organism as a species of Physoderma. Through the kindness of $\mathrm{Mr}$. Price the Canadian locality was visited several times during the spring of 1946 and considerable material in various stages of development obtained. In May, 1946, a large stand of Physoderma-infected plants was located in Washtenaw County about 10 miles from Ann Arbor. These two sites, together with the Wisconsin site noted by Greene, mark the limits of the species as now known. ${ }^{2}$ From observations made around Amherstburg and Ann Arbor, it is apparent the chytrid is definitely localized, more so than the rust, but that when it does occur it is abundant. Furthermore, only very rarely did both rust and chytrid occur in the same stand of plants and only very exceptionally on the same plant. $\Lambda t$ both Ontario and Michigan sites the Physodermainfected plants were almost completely confined to areas beneath a heavy cover of trees and shrubs, and only rarely were such plants found in open meadows or roadsides.

Sympтoms.-Although Greene reported the fungus only on the leaves, it has been observed that the stem, pedicels, inflorescence bracts and sepals are all attacked. The petals and essential organs of the flower, fruit pods, the corm scales, corm and roots, on the other hand, showed no evidence of infection. Where plants were very heavily infected, as evidenced by the large numbers of pustules pres-

${ }^{1}$ Received for publication February 24, 1947.

Contribution from the Botany Department, University of Michigan, No. 842. Acknowledgment is made to the Faculty Research Fund, University of Michigan, for financial aid and to Prof. H. H. Bartlett for making available the services of Eduardo Salgado who prepared plate 1.

2 Greene's report (1945) of the fungus being collected by Wehmeyer from the vicinity of Ann Arbor is erroneous. This material was from the Amherstburg site. ent, very definite stunting occurred, many plants attaining only one-half the typical height. These soon became brown and glassy, toppled over and dried up long before the others. Moderately infected plants do not seem to suffer materially when compared with uninfected ones, although it was universally true that they yellowed and toppled over earlier in the season.

In its earliest stage, the polycentric, endobiotic phase of the fungus forms on the host small, scattered areas, darker colored than normal tissue. Within a week (at Amherstburg, by April 20, 1946) these areas had turned a dark pinkish-brown. Subsequent development involved slight increase in size and, by protrusion of host tissue, formation of individual pustules. These usually occurred singly, only occasionally in dense groups and then primarily at the tips of the leaves. They never became confluent and even on dead leaves remained distinct. On the stem, pustules are found primarily àbove ground, although occasionally they may occur within $3 \mathrm{~cm}$. of the corm. They are usually ellipsoidal, only slightly raised, $1-11 / 2 \mathrm{~mm}$. long by $1 / 2 \mathrm{~mm}$. wide, and are dull brown suffused with a reddish color which often extends in an aureole around the pustule. On the leaf, pustules are found on the margin, on the blade proper, and on the midrib. Protrusion of the pustule may be on either upper or lower surfaces or both. On the leaf blade they are ellipsoidal to nearly circular in outline, and $0.75-2 \mathrm{~mm}$. in greatest diameter, whereas in the midrib region they become distinctly more elongate and usually about $2.5 \mathrm{~mm}$. long by $1 \mathrm{~mm}$. wide. Pustules are occasionally observed on the inflorescence bracts, pedicels and sepals where they vary considerably in size.

Hypertrophy of infected parts was rare except for the floral organs. As shown in the lowermost flower of fig. 3 and 6, not only may contortion and swelling of the pedicel occur, but pronounced hypertrophy of the calyx as well. Heavy infection often results, as in the instances figured, in the almost complete suppression of floral development. Occasionally, the petals may reach maturity, but, as in fig. 4 , the flower fails to open. It was interesting to note that no matter how heavily diseased were the pedicel and calyx, the petals stamens and pistil remained uninfected, although of ten abortive.

A comparison of the pustules of the Physoderma with the telia of the rust reveals in field examination the following points of difference: the Physoderma pustules are distinctly larger, do not protrude so definitely from the host, are dull rather than metallic in sheen, and are surrounded by a distinctly pinkish zone. Once these differences are 


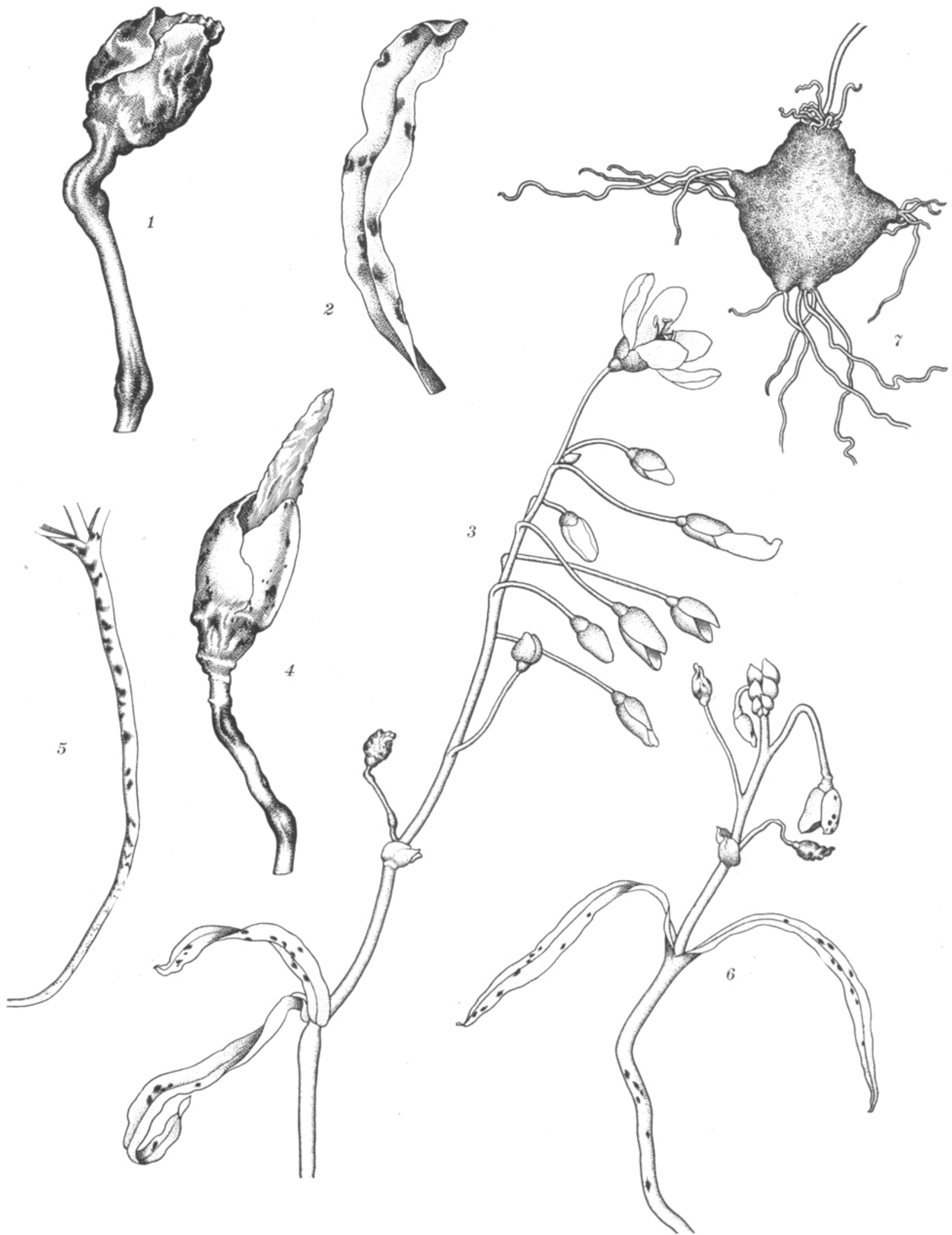

Fig. 1-7. Claytonia virginica infected with Physoderma Claytoniana.-Fig. 1. Heavily infected flower which has failed to open. Two pustules of the Physoderma may be seen on the pedicel.-Fig. 2. Leaf showing pustules due to Physoderma.-Fig. 3. Host plant with leaves and one bud infected.-Fig. 4. Flower with pedicel and calyx infected. 
'ГABLE 1. Summary of measurements on four samples of resting spores of Physoderma Claytoniana.

\begin{tabular}{|c|c|c|c|c|}
\hline \multirow[b]{2}{*}{ Source of sample } & \multicolumn{2}{|c|}{ Length } & \multicolumn{2}{|c|}{ Width } \\
\hline & $\begin{array}{c}\text { Average } \\
\text { measurements }\end{array}$ & $\begin{array}{l}\text { Standard deviation } \\
\text { of measurements }\end{array}$ & $\begin{array}{c}\text { Average } \\
\text { measurements }\end{array}$ & $\begin{array}{c}\text { Standard deviation } \\
\text { of measurements }\end{array}$ \\
\hline \multicolumn{5}{|l|}{ Amherstburg } \\
\hline Stem $\ldots \ldots \ldots \ldots \ldots \ldots \ldots \ldots \ldots \ldots$ & $30.24 \mu$ & $2.33 \mu$ & $25.22 \mu$ & $2.49 \mu$ \\
\hline Leaf $\ldots \ldots \ldots \ldots \ldots \ldots \ldots \ldots$ & $27: 63$ & 2.18 & 23.25 & 2.46 \\
\hline \multicolumn{5}{|l|}{ Washtenaw County } \\
\hline 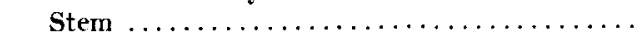 & 30.31 & 2.64 & 25.16 & 2.55 \\
\hline 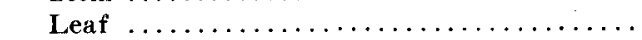 & 27.75 & 2.4 .5 & 22.80 & $\mathcal{2} .29$ \\
\hline
\end{tabular}

${ }^{\text {a }}$ Each sample is composed of 200 spores.

appreciated the two can readily be distinguished without even close examination.

A thorough study of the development of the polycentric endobiotic phase and the epibiotic monocentric phase giving rise to ephemeral sporangia is in progress and will be reported in a later paper.

Resting spores.-Free-hand sections of diseased areas show aggregations of resting spores in various stages of development, turbinate cells and portions of the delicate rhizoidal system, features characteristic of the endobiotic phase of all species of the genus (fig. 8). The resting spores are asymmetrically ellipsoidal in outline, being strongly flattened on one side and are pale-brown and thick-walled. The organization of the contents is entirely similar to that of other species of the genus. Although during their development they bear on the upper part of the more convex surface several short, branched, antler-like haustorial processes (fig. 8), at maturity they are smooth-walled. Minute pits by which these processes were connected to the inner cytoplasm of the spore can occasionally be observed.

TABLE 2. Tests of differences between averages.

\begin{tabular}{|c|c|c|}
\hline \multirow[b]{2}{*}{ Sources compared } & \multicolumn{2}{|c|}{$\begin{array}{l}\text { Differences in } \\
\text { standard units }\end{array}$} \\
\hline & Length & Width \\
\hline \multicolumn{3}{|l|}{ Stem compared with leaf } \\
\hline Amherstburg $\ldots \ldots \ldots \ldots \ldots \ldots$ & 11.3 & 7.9 \\
\hline Washtenaw County ............. & 9.8 & 9.8 \\
\hline \multicolumn{3}{|l|}{$\begin{array}{l}\text { Amherstburg compared with } \\
\text { Washtenaw County }\end{array}$} \\
\hline Stem $\ldots \ldots \ldots \ldots \ldots \ldots \ldots \ldots$ & 0.3 & 0.2 \\
\hline Ieaf $\ldots \ldots \ldots \ldots \ldots \ldots \ldots \ldots$ & 0.5 & 1.9 \\
\hline
\end{tabular}

Preliminary measurements of the sizes of resting spores from the Amherstburg and Washtenaw County sites indicated little if any difference between them. It seemed of interest, however, to study this matter more thoroughly and also to compare the sizes of the spores formed in these leaves with those in the stem. Accordingly, 200 measurements of the long and short axes of spores formed in the leaves, and 200 from those formed in the stem were made from material from the two sites. The following table presents a summary of the simple statistics derived from this series of measurements.

From tables 1 and 2 it may be seen that, using three standard deviations as the level of significance, there is no significant difference between the average lengths and widths of spores (from both stem and leaf) in the Amherstburg and Washtenaw County collections. The statistics do show, however, that the averages of the longer and shorter axes of spores formed in the stems are significantly greater than those in the leaves and that this holds true in material from both sites.

These measurements are greater than those quoted in the original description of the species by Greene which presumably refer to the longer axis of the spore, namely, " ...16-23 $\mu, \ldots$ " This discrepancy is probably due, as Greene (1945) has stated, to the immaturity of the Wisconsin material when collected.

The following expanded and somewhat amended description is proposed for the species.

Physoderma Claytoniana, H. C. Greene, Farlowia $1: 569,1944$.-Epibiotic, monocentric thalli and ephemeral sporangia at present unknown. Endobiotic thallus extensive, polycentric, bearing on its delicate rhizoids 1-3-celled truncate turbinate organs and thick-walled resting spores which bear several short, branched antler-like processes. Resting spores at maturity aggregated, found on stem and leaf in distinct raised, dull brown rounded or ellipsoidal pustules up to $2.5 \mathrm{~mm}$. in greatest diameter, surrounded by a reddish or purplish aureole, on the inflorescence bracts, pedicels and sepals in strongly hypertrophied areas; ellipsoidal, somewhat flattened on one side, $19.8-39.4 \mu$ long by 16-33 $\mu$ wide, the majority 28-30 $\times 23-25 \mu$; wall smooth, amber colored, $2 \mu$ thick, contents granular, often with a large central globule; germinating by the circumscissile dehiscence of a lid.

In stem, leaves, inflorescence bracts, pedicels and sepals of Claytonia virginica, Wisconsin (Greene, l.c.), Washtenaw County, Michigan (F. K. Sparrow); Amherstburg, Ontario (Hazen Price; F. K. Sparrow).

Although the petals were perfectly formed, they did not open.-Fig. 5. Heavily infected stem.-Fig. 6. Plant showing infection on stem, leaves and flowers.-Fig. 7. Corm, showing roots harboring an associated parasite, Polymyxa. 

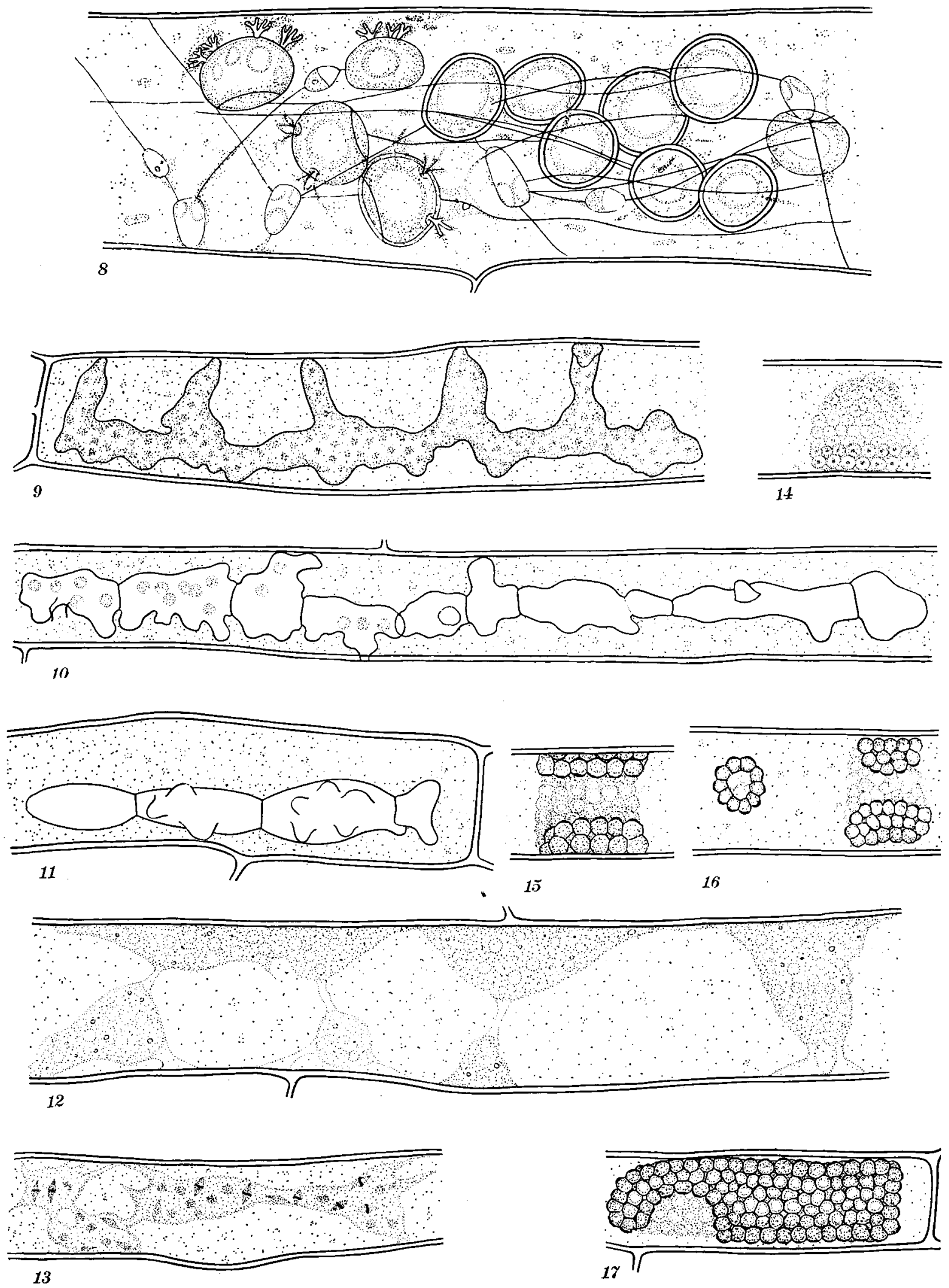

Fig. 8-17. $\times$ 450.-Fig. 8. Portion of host cell showing endobiotic polycentric rhizoidal system and resting spores of the Physoderma.-Fig. 9-17. Claytonia virginica infected with Polymyxa.-Fig. 9. Zoosporangium, nearly mature, 
Associated Parasite. - In an attempt to discover whether or not there were evidences of Physoderma Claytoniana in the subterranean parts of the Spring Beauty, samples of the outer scales of the corm, the corm tissue itself and the roots were examined. No traces of the Physoderma were found. There was discovered, however, in practically every root of a Physoderma-infected plant an undoubted member of the Plasmodiophorales. From this fact, it seemed of interest to determine something of the frequency of occurrence of the two parasites on the same plant. Accordingly twenty Physodermainfected plants and the same number of uninfected plants from approximately the same location at the Washtenaw County site were dug up intact. There were also available in preservative three whole plants from the Ontario site. An interesting fact emerged from this examination, namely, that all the Physoderma-infected plants from both sites also harbored the plasmodiophoraceous fungus in their roots, whereas plants free from Physoderma were also free from the root parasite. This association is a striking one and will be the object of further observations in future growing seasons, particularly with reference to the occurrence in rustinfected plants of the root parasite.

The fungus caused no hypertrophy of the root. In the oldest parts nearest the corm, there were conspicuous clusters of large numbers of brownish, somewhat angular resting spores, which extend for long distances in the cortical tissue. These clusters were usually in the form of open-ended bands which curved around in the host cells (fig. 15, 17). Occasionally they were irregular, or like a potato chip or merely small clumps of few spores (fig. 16). In the occasional root hairs invaded they formed a loose, irregular cluster. In no case was there a common surrounding membrane. The individual spores were angular and 5-6 sided, or somewhat rounded when occurring in loose clusters, and were $3-4 \mu$ in widest dimension.

In younger parts of the root two other structures, undoubtedly formed by the fungus, could be found. The first was the naked plasmodium composed of granular, gleaming vacuolate cytoplasm from which were extruded pseudopodia (fig. 12). Material of this stage preserved in lacto-phenol and stained with acid fuchsin frequently showed faint mitotic figures (fig. 13). It is by fragmentation of this thallus that the clumps of material originate from which the resting spores are formed (fig. 14). The other structures observed were thin-walled, irregularly tubular segmented objects 105-190 $\mu$ long, often with short branches (fig. 9-11). These resembled very strikingly the zoosporangia associated by Ledingham (1939) with his Polymyxa graminis found in roots of cereals. Only quiescent encysted zoospores, $4-5 \mu$ in diameter were observed (fig. 10). Relationships. - As intimated, the root parasite is undoubtedly a species of Polymyxa, a genus closely allied so far as resting spore characters are concerned to Ligniera of the Plasmodiophorales but distinct from it by reason of the formation of elongate, segmented rather than spherical zoosporangia. Because of the striking similarity of the Spring Beauty and cereal parasites, there is little reason at this time to separate the two until convincing data derived from extensive cross-inoculation work indicate specialization on their respective hosts.

\section{SU MMARY}

Physoderma Claytoniana, an obligate parasite of Spring Beauty hitherto known only from Wisconsin and western Ontario, has been found in Michigan. It attacks the stem, leaves, inflorescence bracts, pedicels and calyx, forming on these structures discrete pustules. Heavy infection results in the stunting and early death of the host. Pustules of the Physoderma may be distinguished from those of the common Puccinia Mariae-Wilsoni by their larger size, dull rather than metallic sheen, lesser protrusion from the host tissue and the presence of a pink surrounding zone. A preliminary examination of infected areas reveals the characteristic polycentric endobiotic rhizoidal system bearing turbinate organs and ellipsoidal resting spores flattened on one side. These spores upon germination dehisce a circular operculum. A comparative statistical study of resting spore size in material from Amherstburg, Ontario, and Washtenaw County, Michigan, reveals that, whereas there are no significant differences in size in material from these sites, in both collections the spores from the stem were very definitely larger than those from the leaf. An expanded description of the species is given.

A species of the plasmodiophorous genus Poly$m y x a$, indistinguishable morphologically from $P$. graminis Ledingham, supposedly confined to cereals, has been found in the roots of all Physodermainfected Claytonia plants. It has not thus far been found in material uninfected by the chytrid.

\footnotetext{
Botany Departient,

UNIVERSTTY OF MiChIGAN, Ans Arbor, Michigan
}

\section{LITERATURE CITED}

Greene, H. C. 1944. Notes on Wisconsin parasitic fungi. IV. Farlowia 1:569-581.

. 194.5. Notes on Wisconsin parasitic fungi. VII. Amer. Midl. Nat. 34: 258-270.

Ledingham, G. A. 1939. Studies on Polymyxa graminis, n. gen. n. sp., a plasmodiophoraceous root parasite of wheat. Canadian Jour. Res. 17:38-51. 57 fig.

of the root parasite, Polymyxa.-Fig. 10. Discharged, segmented zoosporangium of Palymyxa with a few encysted zoospores.-Fig. 11. Empty zoosporangium.-Fig. 12. Plasmodia of the Polymyxa.-Fig. 13. Plasmodium stained with acid fuchsin in lacto-phenol; faint mitotic figures are visible.-Fig. 14. Meront in early stages of resting spore formation.-Fig. 15-17. Clusters of resting spores. 